\title{
CONTROLES INTERNOS DA ADMINISTRAÇÃO PÚBLICA
}

\author{
Odete Medaus \\ Professora Associada da Faculdade de \\ Direito da Universidade de São Paulo
}

\begin{abstract}
Resumo: Dentre os inúmeros controles que incidem sobre a Administração Pública se encontram aqueles que a mesma efetua sobre atos e atividades de seus agentes. Pouco valorizados pela doutrina e pela administração, poderiam transformar-se em meio de aprimoramento constante da atividade administrativa. Constitui objetivo deste artigo expor algumas formas de controle interno existentes no Brasil e em outros Estados e também chamar a atenção para as possibilidades que proporcionam à melhoria da atuação administrativa, se considerados com seriedade.
\end{abstract}

Résumé: Parmi les nombreux contrôles que l'Administration Publique subit on trouve ceux quelle même fait sur les actes et les activités de ses agents. Ces contrôles n'ont pas beaucoup de valeur pour la doctrine et pour l'Administration, mais ils pourraient devenir des moyens de perfectionnement de l'activité administrative. Le but de cet article c'est l'exposé de quelques modes de contrôle interne trouvés au Brésil et dans autres États et, aussi, attiver l'attention sur les virtualités que ceux-là offrent pour le perfectionnement de l'Administration, des que envisagés serieusement.

Unitermos: Controle Interno, Controle Administrativo, Autocontrole, Controle de Gestão, Inspeçảo, Ouvidor, Controle Financeiro.

Sumário: 1. Terminologia. 2. Noção. 3. Finalidades. 4. Tipologia. 5. Autocontrole. 6. Controle hierárquico. 7. Controle de gestão. 8. Controle de eficiência. 9. Inspeção, auditoria, correição. 10. Supervisão. 11. Pareceres vinculantes. 12. Ouvidor. 13. Controle financeiro.

\section{CONTROLES INTERNOS DA ADMINISTRAÇĀO PÚBLICA}

1. Terminologia - A fiscalização realizada pela própria Administração sobre os órgãos ou entidades descentralizadas recebe na doutrina várias denominaçōes. Seu estudo, segundo o francês Francis de Baecque, deve ser designado "controle na administraçāo", que é o exercido pela própria administração sobre suas estruturas, para distinguir-se da expressão "controle da administração" que se refere ao controle que, por exemplo, o Parlamento e os administradores exercem sobre a mesma (1) Preferimos utilizar a expressão "controles internos" para designar os vários tipos de fiscalizaçāo existentes no interior da própria Administração Pública, reservando a 
expressão "controle da administraçāo pública", ao estudo das numerosas espécies de controle que sobre a mesma incidem, quer internos, quer externos.

O argentino Dromi emprega o termo "intraorgânico" para referir-se àqueles que ocorrem dentro da organização jurídico-administrativa interna do orgão, seja a administraçāo pública, o Poder Legislativo ou o Poder Judiciário; entre os tipos de controle intraorgânico da Administração Pública Dromi indica o autocontrole. (2)

Com o mesmo sentido que Dromi confere ao vocábulo "intraorgânico", Hely Lopes Meirelles utiliza a expressão "controle administrativo" ao conceituá-lo do modo seguinte: "e todo aquele que o Executivo e os órgãos de administração dos demais Poderes exercem sobre suas próprias atividades..." (3)

Tanto na concepção de Hely Lopes Meirelles quanto na de Dromi, referencial é o poder, o controle do poder, em geral. $O$ reparo que efetuamos ao uso da expressão "controle administrativo" no sentido que lhe dá o primeiro autor é a possibilidade de associação do vocábulo "administrativo" com fiscalização exercida pela Administração Pública sobre os demais poderes, o que não corresponde à acepção que lhe empresta este autor. O termo "intraorgânico", por sua vez, apresenta-se impreciso, ante as divergências existentes quanto à noção de órgão, que aí equivale a "Poder". Parece-nos, portanto, mais clara a palavra "interno", quer se utilize como referencial o "Poder", quer seja a Administração Páblica.

O vocábulo "autocontrole" surge também no estudo do tema, Caio Tacito, (4) na doutrina pátria e Jean Waline ${ }^{(5)}$, na doutrina francesa, que consideram-no sinônimo de "controle administrativo" ou controle que a administração realiza sobre si mesma; segundo o autor francês "por autocontrole entende-se todo controle que se desenvolve no interior mesmo da Administração, por iniciativa da própria Administração ou de um administrado". (6) o argentino Dromi (7) e o uruguaio Jorge Silva Censio ${ }^{(8)}$ conferem sentido mais restrito ao termo - o de fiscalização de um órgão da Administração em relação a seus próprios atos; "todo órgão da Administração seja superior ou subordinado exerce poder de revisão de seus próprios atos, sem necessidade da intervenção de superiores ou estranhos ao sistema orgânico em questão". ${ }^{(9)}$ A existência de duas acepçōes dificulta a compreensão do termo, se utilizado para designar os vários tipos de fiscalização exercida pela Administração Pública sobre si mesma.

O mexicano Alejandro Carrillo Castro menciona os controles "microadministrativos", que se realizam no âmbito de um mesmo órgão e os controles macroadministrativos", exercidos por um ou vários organismos do setor público federal sobre outros, como, por exemplo, no México, a participação de agentes de Ministérios nos conselhos de administração de certas entidades descentralizadas. $(10)$

Consideramos inadequada essa terminologia pela dificuldade de separar uma dimensão "micro" de uma dimensão "macro", nos moldes fixados pelo referido autor, pois segundo suas próprias palavras, pelo controle macroadministrativo órgãos da administração central do Governo Federal exercem controles específicos sobre outras instituições; tratando-se de controle específico, como denominá-los "macro"? Por outro lado, o controle sobre a Administração Descentralizada ou Indireta já recebeu o nome técnico de "tutela administrativa". 
Bergeron utiliza a expressão "controle intra-administrativo", que abrange o setor centralizado e o setor descentralizado. Embora em si a expressão possa ser aceita, surge redundância quando houver menção ao "controle intra-administrativo da Administração Pública.", parecendo soar melhor "controle interno da Administração Pública".

2. Noção $O$ controle interno, segundo Debbasch, é o exercido pela administração sobre si mesma.

Para Forti os controles internos se exercem mediante atos que têm a natureza jurídica de declaraçào de vontade da administração pública, com caráter de atos concretos". ${ }^{(13)}$ Evidente que grande parte da atividade de controle realizada no interior da Administração Pública sobre seus próprios órgãos e entidades resulta na edição de atos administrativos, tal, como apontado por Ugo Forti; no entanto, alguns tipos de atuação fiscalizadora podem não levar diretamente à edição de atos administrativos, como é o caso de um relatório de inspeção que propõe reestruturação de um órgão a ser efetuada por lei.

Mais adequado seria dizer que o controle interno da Administração Pública é a fiscalização que a mesma exerce sobre os atos e atividades de seus órgãos e das entidades descentralizadas que lhe estão vinculadas. Essa noção aplica-se tanto ao controle interno da Administração Pública nos Estados unitários quanto ao controle interno nos Estados Federais ou Estados dotados de entes autônomos (por ex. municípios, regiōes), pois nestes cada nível de poder político é dotado de aparelhamento administrativo próprio, com mecanismos próprios de controle.

3. Finalidades Giannini (14) observa que a doutrina menos recente indica três funçōes tradicionais da Administração Pública: administração ativa, consultiva e de controle, apontadas de modo idêntico por Giuseppino Treves (15). A doutrina mais recente, prossegue o mesmo autor, reparte função da administração ativa em três outras: função cognoscitiva, função decisória e função de atuação; as funçōes consultiva e de controle são reunidas nas chamadas "funçōes complementares".

Tanto no prisma clássico quanto em estudos mais recentes, a função de controle figura como inerente à atividade administrativa. A respeito Bergeron ressalta que tão necessária se apresenta o controle interno que das quatro funções governar, legislar, administrar, julgar - a administração é a única a prever para alguns dos seus funcionários um "status" de controladores por título, como ocorre com os supervisores, inspetores, etc. (16)

Para Bourjol, o problema do controle interno "apresenta importância capital hoje em dia, tanto em virtude do presidencialismo atual (o autor refere-se à França), quanto da decadência do controle político. (17)

Várias finalidades dos controles internos são mencionados pela doutrina.

"Tais controles tendem a conter a ação dos órgãos no âmbito da competência de cada um, a estimular a própria ação e a mantê-la nos limites da legalidade e dos princípios de boa administração". (18)

Segundo Debbasch "esse controle deve permitir verificar se a administração cumpriu suas atribuiçōes conforme os meios jurídicos, técnicos e humanos de que dispõe; é um controle de legalidade, pois deve permitir verificar se a Administração, 
para desempenhar suas atribuições, respeitou certas disposições imperativas ou proibitivas". (19) Ressalta-se ainda que o controle interno de legalidade aparece como instrumento indispensável à aplicação de políticas gerais uniformes, de decisões coerentes, no âmbito da Administração Pública; e como instrumento de aproximação entre indivíduos e Administração Pública.

"É um controle de mérito, pois permite ao controlador grande latitude de apreciação da ação controladora: esta não é confrontada a uma norma determinada, mas a um postulado de boa atuação muito geral, a uma norma de ação ideal, a ser definida pelo controlador quando exerce seu controle". (20) As afirmaçōes de Debbasch merecem pequena ressalva no tocante à ausência de norma determinada para confronto no controle de mérito; por vezes existem diretrizes de governo, programa ou plano de governo ou de ação, que fornecem balizas a quem exerce controle de mérito. Muito pertinente, a propósito, a menção ao caráter político da fiscalização realizada pela Administração sobre si mesma, que se vincula ao mérito das atuaçōes; esse ângulo foi suscitado no resumo e conclusão do Seminário Francomexicano sobre a função de controle na Administração Pública, divulgado na Revista de Administratión Publica. México, jan, abr./ 1973, p.90; esse caráter político decorre dos fins mesmos que lhe são fixados e dos agentes que o realizam.

Para Debbasch é também um controle de rentabilidade, pois coloca em relação custo e produçāo dos serviços; nem sempre o resultado pode ser avaliado quantitativamente, realizando-se, então, o controle sob o aspecto qualitativo; é um controle de eficácia para verificar o respeito à regra do máximo de resultados com o mínimo de esforços.

Hely Lopes Meirelles sintetiza muito bem as finalidades do controle interno quando afirma que este deve operar "para que a atividade pública em geral se realize com legitimidade e eficiência, atingindo a sua finalidade plena que é a satisfação das necessidades coletivas e atendimento dos direitos individuais dos administrados". (22)

4. Tipologia Todas as espécies de controle apontadas no capítulo anterior aplicam-se aos controles internos. Assim, por exemplo, pode ocorrer antes da eficácia de um ato ou medida (controle prévio), simultâneamente à realização do ato (controle concomitante) ou após a edição do ato (controle sucessivo); é acionado de ofício, por provocação ou atua necessariamente no momento oportuno. Mencionem-se ainda o controle exercido sobre os próprios órgãos da Administração Centralizada (Direta) e o controle sobre entidades descentralizadas (autarquias, empresas públicas, sociedades de economia mista, fundaçōes governamentais).

Segundo Puget. ${ }^{(23)}$ os controles internos são gerais ou especiais, estes ultimos incidindo sobre aspectos particulares da atuação administrativa, como é o caso do controle financeiro.

Ao discorrer sobre os diversos institutos do controle interno iniciaremos com os controles internos gerais, prosseguindo, após com o estudo do controle financeiro. 
5. Autocontrole - É a fiscalização exercida pela própria autoridade que editou o ato, ou responsável pela atividade sobre sua atuação; ocorre espontaneamente ou mediante provocação, neste último caso em decorrência de recurso administrativo - pedido de reconsideração ou reclamação, abaixo assinado, etc.

Os Estatutos de Funcionários Civis no Brasil, prevêem de regra o pedido de reconsideraçāo a ser dirigido à mesma autoridade que editou um ato ou tomou medida. Independentemente de menção expressa em textos legais, qualquer pessoa que tenha direitos ou interesses prejudicados por decisōes de autoridades administrativas no Brasil pode utilizar esse recurso para provocar a revisão de medida. Para a autoridade, a interposição do recurso oferece ocasião de refletir novamente sobre a decisão adotada e corrigí-la, se ilegal ou contrária ao interesse público.

Embora na Administração Pública brasileira o pedido de reconsideração seja desprezado pelas autoridades, nem merecendo despacho motivado, com o pensamento de que o interessado se quiser que vá "reclamar seus direitos na justiça", é um excelente meio para propiciar o autocontrole, para ouvir os interessados para buscar atender aos anseios da população e mesmo para realizar a justiça, visto que nảo somente o Poder Judiciário deve concretizá-la, mas também e sobretudo a Administração Pública, cada vez mais ampla, cada vez afetando mais direitos dos indivíduos. A autoridade administrativa deve deixar de lado a recalcitrância ante direitos claramente definidos, por vezes até já reconhecidos pelo Poder Judiciário em casos semelhantes, e rever, reexaminar decisões e medidas espontaneamente ou mediante recurso administrativo do interessado, o que permitirá maior confiança na Administração Pública, atuação mais justa, atendimento ao interesse da coletividade, evitando, por outro lado, sobrecarga do Poder Judiciário.

Como efeito imediato do autocontrole advém ou a manutenção da medida, ou revogação, ou anulação e, no caso de operações materiais anunciadas ou realizadas, novas medidas visando a suspendê-las ou a corrigir efeitos danosos que tenham causado.

6. Controle hierárquico E verificaçāo que os órgāos superiores realizam sobre os atos e atividades dos órgãos subordinados. Na estrutura hierarquizada da Administração Pública, com escalonamento de poderes, o controle exercido pelos superiores configura decorrência lógica, ${ }^{(24)}$ pelo caráter contínuo e automático em que se realiza, pois é inerente ao dia a dia da atividade administrativa.

De acordo com Braibant, Questiaux e Wiener "a vigilância exercida pelos órgãos superiores da hierarquia foi historicamente a primeira e por longo tempo a única forma de controle que a administração conheceu; os detentores do poder, príncipes e depois governantes sempre desejaram direcionar a ação de seus subordinados e dispor de meios de verificar se esta açāo realizava-se conforme as instruçōes dadas ou de acordo com a linha geral que seguiram; invocaram, desde logo, um direito de vigilância de ofício sobre atos editados nos escalōes inferiores e paralelamente consentiram que particulares lhes encaminhassem reclamaçōes contra tais atos" ${ }^{\prime 25}$. 
Da hierarquia decorrem, para o superior, o poder de dar ordens, emitir instruçōes, organizar serviços, comandar a execução de atividades, o poder de avocar, o poder de delegar competências, o poder de fiscalizar atos e atividades dos subordinados, nele incluída a faculdade de revogar, anular, total ou parcialmente, decisōes por estes adotadas. Como bem notam Braibant, Questiaux e Wiener "controle é aqui sinônimo de poder: pelo só fato de que ocupa posição mais elevada na organização administrativa, o superior hierárquico tem qualificação para questionar os atos editados por seus subordinados, que ele pode apreciar tanto do ponto de vista jurídico quanto sob o ângulo da conformidade à política geral imposta ao serviço". (26)

A fiscalização hierárquica pode realizar-se antes da eficácia da medida tomada pelo subordinado, como é o caso das autorizações e mesmo antes que decisões em certo assunto sejam adotadas, para que estas tenham todas certa coerência e uniformidade, expedindo, o superior, circulares, instruções, ordens de sèrviço, etc. com tal finalidade.

Se o superior hierárquico acompanha todo o desenvolvimento da solução de um assunto, a cargo do subordinado, exercerá controle concomitante.

Exercendo-se a fiscalização após a edição do ato ou tomada de decisão, o controle é sucessivo, a posteriori, desencadeando-se espontaneamente, por provocação ou de modo obrigatório, em momento fixado na legislação. No ordenamento pátrio, salvo disposições legais em contrário, o prinćpio é a possibilidade de fiscalização de nfício sobre atos e atividades dos subordinados; alguns ordenamentos limitam a atuação do controle hierárquico, como a Suécia, por exemplo, onde as autoridades superiores só reexaminam decisão de subordinado mediante pedido expresso dos interessados. ${ }^{(27)}$

Recurso administrativo do interessado - na modalidade de recurso hierárquico - aciona também a fiscalização superior, ${ }^{(28)}$ que, no caso, reveste-se, em geral, de grande amplitude, recaindo sobre legalidade e mérito, com possibilidade de alterar a decisão do subordinado não-somente no sentido pretendido pelo interessado, mas também de forma prejudicial (reformatio in pejus).

Ao estudarem a questão da reformatio in pejus, Braibant, Questiaux e Wiener observam que o recurso administrativo pode ser considerado sob ângulo essencialmente subjetivo, como instrumento de defesa de direitos e interesses do indivíduo; em decorrência, a Administração seria obrigada a apreciar o recurso nos termos em que foi interposto; o recorrente não teria agravada sua situação. Sob prisma objetivo, o recurso configura meio de assegurar a regularidade e correçāo da atividade administrativa, cabendo à autoridade competente não só apreciar as alegações do recurso, mas reexaminar, no seu conjunto, o ato impugnado; o recurso desencadeia o controle, mas nảo condiciona a extensão do controle; surgindo a necessidade de reformar para pior, há conflito entre os aspectos subjetivo e objetivo do recurso. (29)

A tendência geral faz prevalecer o aspecto objetivo sobre o subjetivo, admitindo a reformatio in pejus. Na França, o Conselho de Estado firmou jurisprudência no sentido de que a autoridade superior tem a faculdade de reformar ou anular decisão do subordinado, mesmo em sentido contrário à pretensão do recorrente. Nos ordenamentos austríaco, alemão e italiano, da mesma forma, vigora 
a ilimitação para reformar. O direito brasileiro admite igualmente a reformatio in pejus, excepcionando-a em poucas hipóteses, como ocorre com a revisão do procedimento administrativo disciplinar; por exemplo, o Estatuto dos Funcionários Públicos do Estado de São Paulo (art. 313) e o Município de São Paulo - Lei $\mathbf{n}^{\mathbf{Q}}$ 8.989 , de 29 de outubro de 1979 - (art. $220,2^{\circ}$ ) vedam que a pena seja agravada em conseqüência da revisão.

Há ordenamentos em que vigora o preceito inverso. Assim, no direito espanhol jurisprudência fixada a partir de 1972 proibe a reformatio in pejus de atos administrativos objeto de recurso, devendo as exceções ter previsão em lei. ${ }^{(30)}$

Quanto à possibilidade de reformar para melhorar, concedendo-se ao recorrente mais do que solicitou, é amplamente admitida, não se registrando, então, conflito entre os aspectos subjetivo e objetivo do recurso.

O controle hierárquico pode também ser desencadeado pela intervenção de órgãos de controle externo institucionalizado, como por exemplo, "Ombudsman", ou ainda por noticiário de imprensa, manifestação de parlamentares nas tribunas, movimentos populares, etc.

Mencione-se mais o chamado controle hierárquico "obrigat6rio", a atuar em momento fixado em normas legais, sem que a autoridade superior tenha a faculdade de omitir-se. E o caso, por exemplo, das homologações, que, no ordenamento pátrio, aparecem como uma das fases ou atos do procedimento licitatório, do procedimento de concurso público para preenchimento de cargos e do procedimento de concursos de carreira universitária.

Apontam-se freqüentemente aspectos favoráveis do recurso hierárquico, como os seguintes: menos formalista e oneroso que a via jurisdicional; permite fiscalização mais abrangente da atuação administrativa, sobretudo no tocante ao mérito; propicia aprimoramento nas relaçōes indivíduo-Administração. Em contraposição invocam-se também os pontos desfavoráveis, sobretudo em ordenamentos como o pátrio em que, de regra, inexiste disciplina legal para o recurso hierárquico e em que, na atividade cotidiana da administração, o recurso hierárquico nâo desfruta de prestígio, como já se disse, predominando a mentalidade de esperar que o interessado utilize a via jurisdicional, mesmo na hipótese de direitos óbvios: o esprit de corps ou solidariedade entre os diversos escalōes da hierarquia; agentes executores atuam com base em instruções de superiores e na aplicação de diretrizes políticas que se impōe a estes também ${ }^{(31)}$.

7. Controle de gestão - A rigidez no funcionamento da estrutura hierarquizada da Administração, a conseqüente diluição de responsabilidades, os aspectos desfavoráveis do controle hierárquico acarretam a busca de novos métodos de direção e novas técnicas de controle. No seminário Franco-mexicano sobre a função de controle na Administração Pública, realizado no México em 1973, o francês Jean Costet, propôs a chamada "gestão por objetivos", do que decorreria o controle de gestão, recomendado nas conclusōes do simpósio. Em síntese, o referido autor expõe o seguinte: "a gestão observa três fases: determinação dos objetivos e dos programas; medida dos resultados, verificação dos desvios; execução de ações corretivas; o controle dessa gestão baseia-se em objetivos de realização ou de produção; o esquema geral dessa gestão por objetivos parece simples: definem-se 
produtos e produções; cada centro da responsabilidade vê fixados, para a realização de certos resultados e após diálogo, objetivos de ação relativos a nível de despesa, qualidade, quantidade, respeito aos programas; para cumprí-los, cada centro de responsabilidade recebe delegações de autoridade; a realização do controle requer a utilização de indicadores de gestão, a execução de um orçamento apoiado por uma análise de custo em nível refinado; quadros periódicos efetuam a síntese das informaçōes, as quais por comparação com os objetivos permirem a realização permanente de ações corretivas". ${ }^{(32)}$ Segundo o mesmo autor, a noção de "chefe de projeto" é o corolário dessa nova concepção das relações entre os diferentes escalöes da Administração; para uma realização claramente definida, preferivel é a designação de um responsável único (chefe de projeto) que atribuí-la às estruturas hierárquicas tradicionais que dividem as responsabilidades. ${ }^{(33)}$

No resumo e conclusão do referido Seminário constam as seguintes afirmações sobre o controle de gestão: "a importância do controle de gestão deu origem a certo número de tentativas de modificar a prática de um controle hierárquico que não corresponde mais às necessidades atuais; o controle de gestão permite evitar a diluição da responsabilidade dos executores; os estudos relativos ao controle de gestão possibilitaram estruturar a técrica da gestão por objetivos, que repousa sobre resultados ou realizaçōes da gestão; a gestão por objetivos supōe a definição de objetivos, fixados para cada ação, e dos meios disponíveis a fim de bem realizá-la. (34)

O controle de gestão vem mencionado por Giannini que o caracteriza como controle incidente sobre atividade total ou parcial do controlado, sobretudo sob o aspecto dos resultados da gestão; os controles de gestão têm diferentes amplitudes e finalidades, indo desde os controles da gestão em sentido estrito, dos quais a figura mais destacada é a da auditoria do direito anglo-saxão, aos controles que utilizam técnicas muito refinadas, nos quais a atividade de controle torna-se instrumental em relação a uma atividade de direção do controlado; novas espécies também são propostas, como os denominados sistemas integrados: há uma planificação ampla na qual se insere programação e objetivo com tempo limitado, com determinação dos meios a empregar; periodicamente verifica-se o emprego dos meios em relação à programação e aos resultados e, mediante ordens, efetuam-se os ajustes da programação ou dos meios ou adotam-se medidas mais graves, como substituição de pessoas, encerramento do programa, etc. ${ }^{(35)}$

O mesmo autor bem observa que na ciência da Administração a figura predileta $e$ o controle de gestão ou de eficiência, vendo-se com desfavor o controle de legalidade e o controle de mérito, porque limitados a atos isolados e, portanto, pouco profundos e com resultados demorados; assinala ser significativa essa mudança de concepção porque significa índice de uma visão da Administração fundada na eficiência, ainda segundo Giannini, absorvem os de legalidade e o superam com o uso mais rico de parâmetros de controle, além do mais, a diversos tipos de Administraçäo. ${ }^{(36)}$

Acreditamos que dificilmente se atingirá o ponto de abolição total do controle hierárquico, no aspecto de legalidade ou de mérito, embora se devam buscar novas técnicas de gestão e em decorrência novas técnicas de controle, de que é exemplo o controle de gestão. Evidente que um controle tão abrangente como o 
de gestão, que recai sobre um conjunto de atividades desenvolvidas para atendimento de um objetivo, absorve o de legalidade e o de mérito e tem a vantagem, segundo se depreende, do acompanhamento simultâneo da atuação, com medidas corretivas a cada passo, impedindo a dispersăo e o mau uso dos recursos alocados; por outro lado, quebra a rigidez da estrutura hierarquizada, sem deixar, no entanto, de observar certo escalonamento, pela existência de um agente controlador e de um chefe de projeto. Necessário se torna tentar aplicar essa nova técnica e estudar os resultados, a exemplo do ocorrido na França, que em 1968 iniciou uma experiência-piloto no Ministério da Ordenação do Solo, com resultados positivos, segundo informação oferecida no Seminário Franco-mexicano sobre a função de controle na Administração Pública, já citado. (37)

8. Controle de eficiência - Segundo Giannini configura "espécie limitada do controle de gestão, porque destinado a verificar, com base em indicadores de eficiência, a atividade do controlado; resulta numa determinação, dirigida à autoridade controlada, de realizar ou não realizar algo ou uma proposta que se apresenta a outra autoridade para que intervenha com atos repressivos". (38) Essa fiscalização efetua-se, muitas vezes, informalmente, mediante ordens ou solicitações de autoridades de escalões superiores, nem sempre na linha direta da hierarquia, com prazo para atuaçōes ou manisfestaçōes de agentes situados em graus inferiores.

9. Inspeção, auditoria, correiçäo - Esses três tipos de atividade de controle guardam semelhanças em dois aspectos principais: destinam-se, de regra, a oferecer informações e dados sobre os serviços controlados a autoridades com poder de decisão nesses setores; embora inseridos na estrutura hierárquica interna da Administração, nem sempre situam-se na linha direta de hierarquia do órgão controlado; são desprovidos de poder de decisão, culminando a atividade fiscalizadora com a elaboração de relatórios dirigidos à autoridade com poder de decisão, nos quais expōem o que verificam e propōem medidas; gozam, junto aos órgäos controlados, de poderes de investigação, exame de papéis e documentos, ouvida de funcionários, etc. Às vezes, os agentes dessa atividade de controle realizam outras funçōes, como assessoria ou gestão direta.

Exemplo típico de inspeção encontra-se na França, integrando o rol das suas tradições muito antigas, considerada, na origem, instrumento de centralizaçāo do aparelhamento administrativo. (39) Além de funções de assessoria e informação do Ministro respectivo, os "corpos de inspeção" na França exercem funçōes de gestão direta; mas sua tarefa principal é a de controle; a tendência hoje, na administraçāo francesa, consiste em situar os corpos de inspeção em vinculação direta com o Ministro respectivo; a maioria das inspeções gerais atuam sob a autoridade de um chefe de inspeção; os corpos de inspeçāo redigem relatório a respeito das atividades dos serviços controlados, para que um agente superior ou o Ministro tomem as decisöes pertinentes. ${ }^{(40)}$

Segundo Jean Waline a administração francesa comporta inspeçōes gerais, inspeçōes com atuação mais limitada e algumas inspeçōes de caráter interministerial; sob esse aspecto o principal problema encontra-se na conveniência ou não de criar um corpo geral de inspeção que se destinaria ao conjunto das 
administraçōes do Estado ("inspetores do Estado"); outra questão que vem merecendo discussão diz respeito às funções desempenhadas, registrando-se uma tendência no sentido de retirar-lhe as funções de controle sistemático, atinentes ao poder hierárquico; sua tarefa deveria restringir-se à apreciação direta e indiscutível de fatos. ${ }^{(41)}$

O termo "auditoria", embora habitualmente vinculado ao controle financeiro, também aplica à fiscalização geral da atividade administrativa, especialmente quando realizada in loco, de modo inopinado. Na Administração Pública brasileira ainda é pouco utilizado nesta acepção.

Por sua vez, a correição tem uso mais freqüente, semelhante à inspeção do sistema francês. Tanto se apresenta como controle geral da Administração quanto fiscalização setorizada, de atos e atividades de determinado órgão da Administração. Exemplo do primeiro tipo encontra-se na Administração do Estado de São Paulo; pelo art.61 da Lei Estadual $n^{2}$ 6.057, de 24 de março de 1961 institui-se a Corregedoria Administrativa do Estado; de acordo com o Decreto $\mathbf{n}^{2} 23.596$ de 24 de junho de 1985 atualmente é unidade da estrutura da Secretaria do Governo, vinculada ao governador do Estado; cabe-lhe preservar os padrões de legalidade e moralidade dos atos realizados pela Administração Centralizada e Descentralizada do Estado, com vistas à proteção e defesa dos interesses da sociedade; compõem-se de um presidente e de até vinte corregedores, portadores de nível universitário, designados pelo governador do Estado, para servirem com ou sem prejuízo de suas atribuiçōes normais; a Corregedoria realiza inspeçōes por determinação do governador ou do secretário do Governo; em decorrência de representação de agentes públicos ou particulares; de ofício, ao tomar conhecimento de irregularidades, inclusive pela imprensa; os corregedores têm livre acesso a todas as dependências dos órgãos da Administração Centralizada e Descentralizada; aos secretários de Estado e dirigentes de entidades serão encaminhados relatórios resumo das inspeçōes realizadas nas respectivas áreas, com indicação das recomendações adotadas.

Exemplo de correição específica encontra-se na Procuradoria Geral do Estado; nos termos de sua lei orgânica - Lei Complementar $n^{2} 478$, de 18 de julho de 1986 - entre os seus 6rgãos superiores inclui-se a Corregedoria, chefiada por um corregedor-geral e por corregedores auxiliares, em número máximo de doze, todos procuradores do Estado; compete à Corregedoria, dentre outras atribuições, fiscalizar as atividades dos órgãos da Procuradoria-Geral do Estado e neles realizar correiçōes, sugerindo as medidas necessárias à racionalização e eficiência dos serviços.

Tais espécies de controle interno, como se percebe, culminam com a elaboração de relatório, no qual se expōem, falhas, irregularidades ou ineficiências verificadas e se recomendam medidas a quem possa adotá-las, ou melhor, à autoridade dotada de poder de decisão. Reside aí, a nosso ver, o ponto crucial desse controle; por mais eficiente e perspicaz que seja a inspeção, auditoria ou correição, suas conclusões e medidas propostas ficam na dependência da autoridade superior, que nem sempre está interessada em tomar conhecimento dos relatórios oferecidos e das medidas sugeridas. Como bem nota Debbasch a respeito das inspeçōes na França, com freqüência quando os agentes de inspeção ou auditoria remetem seus 
relatórios, a urgência política, que havia levado a autoridade superior a acionar essa fiscalização, não mais existe e a autoridade deixa de interessar-se pelos resultados das investigaçōes; só a publicidade dos relatórios, pela atenção da opinião pública, permitiria evitar seu engavetamento constante. ${ }^{(42)}$

10. Supervisão O vocábulo "supervisão" admite acepção associada a controle. A Constituição Federal de 5 de outubro de 1988, entre as atribuições dos Ministros, prevê a supervisão dos órgãos e entidades da Administração Federal na área de sua competência (art.87, único, ítem I). A expressão "supervisão ministerial" aparece no Decreto-Lei $n^{2} 200 / 67$, objeto de disciplina nos artigos 25 a 29 , relativa à administração direta e administração indireta. No tocante à supervisão no âmbito da primeira, que nos interessa no momento, cabe ao Ministro do Estado, com apoio dos órgãos centrais do respectivo ministério; conforme dispõe o parágrafo único do art.20, a supervisão ministerial abrange a orientação, a coordenação e o controle das atividades dos órgãos subordinados ao ministério, do que se conclui que, na esfera federal, supervisão não se reduz a controle; este é um dos aspectos da supervisão ministerial, equivalente, assim, ao controle hierárquico.

$\mathrm{Na}$ área do ensino de $1^{2}$ e $2^{2}$ graus, no âmbito municipal e estadual, encontra-se a figura do "supervisor", que substitui o antigo "inspetor". O supervisor atua como intermediário entre o estabelecimento de ensino e os brgãos administrativos, como, por exemplo, delegacias de ensino; exerce função de controle da atividades dos estabelecimentos, sobretudo quanto ao atendimento de normas legais e diretrizes fixadas pelos órgãos superiores do ensino; mas, a tarefa de auxilio na gestão, pelo acompanhamento da execução; por outro lado, aos supervisores atribuem-se poderes de, até determinado nível, editar medidas para corrigir irregularidades verificadas, inclusive punitivas; no ensino do Município e do Estado de São Paulo o supervisor é superior hierárquico do Diretor de Escola.

11. Pareceres vinculantes Braibant, Questiaux e Wiener, ao estudarem os controles preventivos apontam, como primeiro instrumento, os órgãos consultivos acionados para oferecer parecer prévio sobre projetos de decisão; segundo os mesmos autores, as cidades antigas e as monarquias de direito divino conheciam já esses "conselhos de sábios", de "antigos", de "legistas", que davam aos chefes pareceres fundamentados em princípios jurídicos, embora com independência reduzida. ${ }^{(43)}$

Discordamos dos citados autores franceses no concernente às consultas facultativas, cujos pareceres não vinculam a autoridade dotada de poder de decisão. Em tais casos a consulta e os pareceres decorrentes configuram, como bem expõe Guy Isaac, medidas de instrução no procedimento de tomada de decisão. ${ }^{(44)} \mathrm{De}$ modo coerente com o conceito de controle que adotamos no Capítulo II, foge às técnicas de controle a consultoria facultativa e o parecer que não obriga ou mesmo a consulta obrigatória, sem parecer vinculante.

Diferente se apresenta a situação em que a autoridade administrativa é obrigada a realizar consulta prévia, cujo parecer vincula a decisão a ser tomada, não deixando liberdade, salvo a de não emanar o ato. A respeito manifestam-se Berti e Tumiatti: "entre os atos de controle aqui examinados alguns autores incluem 
também os pareceres vinculantes, dos quais, embora para casos não freqüentes, os órgãos ativos devem munir-se antes da edição do ato administrativo e aos quais devem ater-se sob pena de invalidade do mesmo ato. Há controversia na doutrina a respeito da natureza e da função atribuída a tal tipo de atividade, que sob certos aspectos é consultiva e sob outros aproximam-se muito da função de controle...; há, no entanto, hipóteses legislativas nas quais é difícil negar ao parecer vinculante semelhança estreita com a autorização. Trata-se dos casos em que o legislador prevê que a edição de alguns atos seja procedida do parecer favorável de determinados órgãos, de regra técricos.. " ${ }^{(45)}$ Nesses casos o parecer condiciona o conteúdo do ato; se a autoridade discordar do entendimento fixado só the resta a alternativa de não editar 0 ato.

12. Ouvidor - Numa imitação distorcida do instituto de controle denominado "Ombudsman", que estudaremos no tema dos controles externos, vêm surgindo ultimamente órgãos ou autoridades de controle interno, inseridas na estrutura hierárquica da Administração, que recebem diversas denominações, tais como Comissário Presidencial para Queixas e Reclamaçōes, Conselho de Defesa dos Direitos do Cidadão, Ouvidor-Geral, Ouvidor.

Em 1969 criou-se na Venezuela o Comissário Presidencial para Queixas e Reclamaçōes, vinculado ao Poder Executivo, que cessou de funcionar em 1974.

No Brasil, em maio de 1986, por decreto do Presidente da República, foi instituído o cargo nåo remunerado de Ouvidor-Geral da Previdência, a ser provido pelo chefe do Executivo Federal, por indicação do Ministro da Previdência, entre cidadãos de notória reputação e reconhecido espírito público; em cada Estado haverá um Ouvidor; a função do Ouvidor da Previdência consiste no recolhimento de informações, queixas e denúncias dos usuários da Previdência Social.

Igualmente por decreto do Presidente da República, de 3 de janeiro de 1986, criou-se a Comissão de Defesa dos Direitos do Cidadão (CODECI), vinculada ao gabinete do Presidente, chefiada por um Ouvidor-Geral e integrada por servidores da Presidência da República, com a função de receber reclamaçỏes do povo contra a administração federal, direta e indireta, concessionários de serviços públicos e demais instituições que executem serviços delegados pelo poder público federal; a reclamação a ser encaminhada à CODECI deve conter assinatura do reclamante e estar acompanhada de documentos comprobatórios ou indicaçáo de outras provas, inclusive testemunhal: as reclamaçōes podem ser remetidas à Comissão ou por meio de qualquer repartição federal.

A manisfestação do professor venezuelano Brewer Carias a respeito do Comissário Presidencial daquele país aplica-se totalmente aos ouvidores brasileiros: "estas instituiçōes, em primeiro lugar, foram criadas pelo Presidente da República, de maneira que não tinham nível de lei ou de preceito constitucional; em segundo lugar, não podiam atuar de modo independente em relação à Administração Páblica, dada sua subordinaçăo ao Executivo Nacional; em terceiro lugar, não tinham competências decisórias próprias, mas atuavam como tramitadoras das queixas ou reclamações aos diversos órgãos legalmente competentes: e, por último, não tinham por missão controlar nem vigiar os direitos e liberdades públicas ante a ação administrativa mas, em geral, o funcionamento da Administração Pública". (46) 
Em editorial sob o título "Mas que ombudsman esquisito!", de 18 de dezembro de 1986, p.3, o jornal O Estado de Sāo Paulo teceu apropriadas críticas à referida Comissão, do qual ressaltam os seguintes trechos: "Por uma questão de simples bom senso, a condição preliminar de funcionamento de uma instituição desse tipo, em defesa dos direitos dos cidadãos - tal caso do "ombudsman" sueco ou do "Defensor do Povo" espanhol , é sua independência, sua plena autonomia em relação ao próprio governo. Só pode ser imaginada tal instituição como pertencente exclusivamente à sociedade civil, desvinculada de órgãos governamentais e de poderes do Estado - principalmente do Executivo, do qual se incumbiria de exercer ampla cobrança em nome da sociedade... Os organismos da administração direta e indireta não teriam os seus instrumentos de controle, de fiscalização, de auditoria? Não teriam seus setores de atendimento dos cidadãos, inclusive no campo de queixas e reclamações parte inerente a qualquer tipo de serviço público?"

13. Controle financeiro - E um controle interno específico, que incide sobre os aspectos financeiros dos atos e atividades da Administração Pública. Segundo Puget, grande parte das atividades administrativas acarretam despesas e freqüentemente é necessário o acordo de dois órgãos distintos, o que realiza a despesa e o que paga; a divisão entre o gestor e o pagador propicia controles exercidos por uma dessas autoridades sobre a outra; sobre o conjunto dos órgãos administrativos incidem controles de um único órgão, de regra um Ministério ou Secretaria da Fazenda ou do Planejamento; ou, por delegação de competência, instituem-se corpos de controle financeiro".

No tema do controle financeiro em geral, deve-se distinguir o controle das operações financeiras em realização e o controle de contas.

a) Controle das operaçōes financeiras em realização - No Brasil essa fiscalização é exercida pelo próprio Executivo, mediante sistema de controle interno, com a finalidade de:

I- avaliar o cumprimento de metas previstas no plano plurianual, a execução dos programas de governos e dos orçamentos da União; II- comprovar a legalidade e avaliar os resultados quanto à eficácia e eficiência, da gestão orçamentária, financeira e patrimonial nos órgāos e entidades da administração federal, bem como da aplicação de recursos públicos por entidades de direito privado; III- exercer o controle das operaçóes de crédito, avais e garantias, bem como dos direitos e haveres da União (art.74 da Constituição Federal de 5 de outubro de 1988).

Na Administração Federal, em cada Ministério Civil há uma secretaria de controle interno, antiga Inspetoria Geral de Finanças, que tem, entre suas atribuiçōes, a do controle das operaçōes financeiras em realização (Decreto $\mathrm{n}^{\mathrm{a}}$ 84.362, de 31 de dezembro de 1979, artigo $1^{2}$ inciso II). A Secretaria Central de Controle Interno, subordinada diretamente ao Ministro-Chefe da Secretaria de Planejamento (artigo 10 do decreto acima); era a Inspetoria-Geral das Finanças do Ministério da Fazenda. Cabe à Secretaria Central de Controle Interno a execuçảo, em caráter exclusivo, de auditoria contábil e de programas, tanto de órgãos da administração direta, quanto de entidades da administração indireta, sem prejuízo da supervisão ministerial, entre cujas finalidades encontra-se também a de fiscalizar 
a aplicação e utilização de dinheiros, valòres e bens públicos (art. 25, inciso VIII, do Decreto-Lei $\left.\mathrm{n}^{\mathrm{Q}} 200 / 67\right)$.

Na França há um "Controlador Financeiro", escolhido pelo Ministro da Economia e Finanças entre altos funcionários ou da Corte de Contas ou da inspeção de finanças ou desse mesmo Ministério; o Controlador apõe seu visto em todas as despesas, que não podem ser realizadas sem esse aval.

$\mathrm{Na}$ Inglaterra esse controle é exercido por funcionários da Tesouraria, destacados em cada Ministério. ${ }^{(48)}$

Nos Estados Unidos um controle conjunto das operações financeiras efetuase pelo Ministério do Tesouro e "Bureau" do Orçamento; há a figura do "Controlador Geral", que chefia o "General Accouting Office", competente, na origem, para examinar somente contas; mas em razão do seu poder de declarar inexistente toda despesa maljustificada, passou a receber consultas prévias das unidades administrativas, que, desse modo, procuram evitar declaração de irregularidades posterior.

$\mathrm{Na}$ Espanha o controle financeiro prévio interno efetua-se pela intervenção geral da Administração do Estado, com intervenções delegadas em Ministérios e organismos autônomos e intervençôes especiais nos Ministérios Militares.

b) Controle de contas - Órgãos financeiros ou contábeis da Administração examinam, isto é, o modo como foram efetuadas despesas, antes de sua remessa aos Tribunais de Contas respectivos, onde existirem.

$\mathrm{Na}$ administração federal brasileira, os trabalhos de auditoria contábil, de competência exclusiva da Secretaria Central de Controle Interno, incluem a prestação de contas e o exame da documentação instrutiva ou comprobatória da despesa (Decreto $n^{2} 84.362$, de 31 de dezembro de 1979, art. 18, 2, "b" e "c".

$\mathrm{Na}$ Inglaterra, além do controle prévio da despesa, o Controlador Auditor Geral examina prestação de contas com a ajuda de assessores, apresentando, depois, relatório ao Parlamento.

O "General Accouting Office", encabeçado pelo Controlador Geral $\varepsilon$ responsável, nos Estados Unidos, pelo exame das contas, tendo o poder, como já se mencionou, de declarar inexistente toda despesa que the parecer malfundamentada.

\section{Referências Bibliográficas}

1. "Le Contrôle dans l'Administration, in Revista de Administration Publica, México, jan.abr./1973, p. 7 .

2. "Prerrogativas y Garantias Administrativas", 1979, p.18 e 20.

3. "Direito Administrativo Brasileiro", 15ª ed, 1990, p. 566.

4. "Direito Administrativo", 1975, p. 280. 
5. "L'evolution du Contrôle' de l'Administration depuis un Siecle", Revue du Droit Public et de la Science Politique, set./out, 1984, p. 1335.

6. Op. cit., p. 1335.

7. "Prerrogativas y Garantias Administrativas", 1979, p. 20.

8. "El Control de la Administratión", Revista de Direito Páblico, $n^{2} 38 / 40$, jul./dez, 1976, p.8.

9. DROMI. "Prerrogativas y garantias Administrativas", 1979, p.20.

10. "La Fonction de Contrôle dans l'Administration Publique Mexicaine", in Revista de Administration Publica, México, jan./abr, 1973, p. 14.

11. "La Fonctionnement de l'État", Paris, 1965, p. 217 e 272.

12. "Science Administrative", Paris, 1976, p. 643.

13. "I Controlli dell'Amministrazione Communale", in "Primo Tratato Completo di Diritto Amministrativo Italiano, de ORLANDO, vol. $2^{2}, 2^{8}$ parte, 1915, p. 619.

14. "Istituzioni di Diritto Ammnistrativo, 1981, p. 47.

15. "Les Contrôles Administratifs et Fiananciers à l'interieur de l'Administration", in Revue Internationale des Sciences Administratives, Bruxelas, vol. XXXV, ne 4, 1969.

16. "Fonctionnement de l'Etat", 1965, p. 272.

17. "Droit Administratif", $2^{\mathrm{a}}$ parte ("Le contrôle de l'action administrative"), Paris, 1973, p. 26.

18. BERTI e TUMIATI, "Controlli Ammnistrativi", Enciclopodia del Diritto, tomo X, 1962, sotto voce Controllo.

19. "Science Administrative", 1976, p. 643.

20. DEBBASCH, "Science Administrative", 1976, p. 644.

21. Op. cit, p. 644.

22. "Direito Administrativo Brasileiro", $15^{\circ}$ ed., 1990, p. 566.

23. "Les Institutions Administratives Étrangeres", Paris, 1969, p. 170. 
24. "Direito Administrativo Brasileiro", 1990, p. 567.

263.

25. "Le Contrôle de l'Administration et la Protection des Citoyens", 1973, p.

26. Op. cit., p. 265.

27. BRAIBANT, QUESTLAUX e WIENER, op. cit., p. 265.

28. Os aspectos fundamentais relativos aos recursos administrativos podem ser estudados em CRETELLA JUNIOR, "Tratado de Direito Administrativo", vol. VI, p. 231-276 e Odete MEDAUAR, "Recursos Administrativos", Revista dos Tribunais, vol. 583, maio de 1984, p. 9-16.

29. Op. cit., p. 278.

30. GARCLA de ENTERRIA e RAMON FERNANDEZ, "Curso de Derecho Administrativo, vol. II, Madri, 1982, p. 457. Referido autor, vendo o recurso predominantemente como garantia para o administrado, aplaudindo a jurisprudência do seu país.

31. BRAIDANT, QUESTIAUX e WIENER, "Le Contrôle de l'Administration et la Protection des Citoyens", 1973, p. 279.

32. JEAN COSTET, "Le Controle Hierarchique" in Revista de Administración Publica, México, jan./abr, 1973, p. 78.

33. Op. cit., p. 78.

34. "La Fonction de Contrôle dans l'Administration Publique - Résumé et Conclusion", in Revista de Administración Publica, México, jan./abr, 1973, p.86.

35. "Istiturioni di Diritto Ammnistrativo", 1981, p. 51-52.

36. Op. cit., p. 56 , nota 14.

37. JEAN COSTET, "Le Contrôle Hierarchique", in Revista de Administración Publica, México, jan./abr, 1973, p. 79.

38. Istituzione di Diritto Ammnistrativo", 1981, p. 52.

39. JEAN WALINE, "L'Evolution du Controle de l'Administration depuis un Siecle", in Revue du Droit Public et de la Science Politique, set./out, 1984, p. 1337.

40. DEBBASCH, "Science administrative", $3^{3}$ ed., 1976, p. 646-648. 
41. Op. cit., p. 1337-1338.

42. "Sciene Administrative", 1976, p. 651. 233.

43. "Le Contrôle de l'Administration et la Protection des Citoyens", 1973, p.

44. "La Procedure Administrative Non Contentieuse", Paris, 1968, p. 455.

45. "Controlli Amministrativi", in Enciclopedia del Diritto soto voce Controllo.

46. "Garantias Constitucionais dos Direitos do Homem", Caracas, 1976, p. 91-93, apud DROMI, Prerrogativas y garantias administrativas, 1979, p. 28.

47. "Les Institutions Administratives Étrangeres", Paris, 1969, p. 171.

48. PUGET, "Les Institutions Administratives Étrangeres", 1969, p. 172.

49. PUGET, op. cit. p. 172-173.

50. MATEO, Ramón Martin. "Derecho Administrativo", Madri, 1980, p. 182.

São Paulo, janeiro de 1990. 